\title{
Artelogie
}

Recherche sur les arts, le patrimoine et la littérature de l'Amérique latine

$8 \mid 2016$

Transgression dans les arts / transgression des arts

\section{El arte de la transgresión en la plástica femenina: México el legado de los 70s y 80s}

\section{Araceli Barbosa Sánchez}

\section{OpenEdition}

\section{Journals}

Edición electrónica

URL: http://journals.openedition.org/artelogie/441

DOI: 10.4000/artelogie.441

ISSN: 2115-6395

Editor

Association ESCAL

Referencia electrónica

Araceli Barbosa Sánchez, «El arte de la transgresión en la plástica femenina: México el legado de los 70s y 80s », Artelogie [En línea], $8 \mid$ 2016, Publicado el 26 enero 2016, consultado el 10 diciembre 2020. URL : http://journals.openedition.org/artelogie/441 ; DOI : https://doi.org/10.4000/artelogie.441

Este documento fue generado automáticamente el 10 diciembre 2020.

Association ESCAL 


\title{
El arte de la transgresión en la plástica femenina: México el legado de los 70s y 80s
}

\author{
Araceli Barbosa Sánchez
}

\section{Transgresión/dialógica/arte}

1 La transgresión se ha manifestado en todos los ámbitos del acontecer humano a través de la historia. Opera en los diversos dominios donde la interdicción se prescribe para garantizar el orden mediante el cumplimiento de la ley o la observancia de la regla. No obstante, también se constituye como un recurso generador de cambio, que deviene consustancial a la transformación, toda vez que se opone a los fundamentos que legitiman un orden establecido, a su ideología, al cumplimiento de sus normas y valores, por lo que se le inflige la censura y la sanción. Por tanto, transgresión ${ }^{1}$ y castigo resultan concomitantes en el proceso que conduce a la realización de la utopía, mientras que la primera allana el camino para su realización, el segundo le opone resistencia con el propósito de obstaculizarla, frenarla y eliminarla. Esto significa que el binomio transgresión/liberación mantiene una relación dialógica ${ }^{2}$ de interdependencia a partir de su indisoluble unidad constituida por la asociación dinámica de dos términos, que no obstante ser antagónicos se complementan de forma concurrente. Es así que la dialógica del conocimiento asume la unidad en su diversidad, con lo cual se trasciende la lógica binaria que simplifica la complejidad mediante la oposición y la exclusión. Es mediante esta perspectiva que el concepto de la transgresión requiere ser abordado. Asimismo, tener en cuenta que su dinámica dialógica merece caución, ya que también se puede ejercer para implantar el socavamiento de los derechos humanos; entonces, el binomio transgresión/esclavitud, justificará la opresión. En este sentido, su potencial entraña poderosas fuerzas que conducen a la degradación de la condición humana. De ahí que la transgresión posea un carácter ambivalente, dependiendo de los propósitos que se persigan. Lo mismo se puede subvertir, sublevar en nombre de la libertad y la 
consecución de la utopía ; o bien vulnerar, violar o abolir la libertad ; y en consecuencia gestar el advenimiento de la distopía.

Desde la perspectiva epistemológica de la complejidad, ${ }^{3}$ la comprensión del arte transgresor conlleva el reconocimiento de su condición dialógica, con el fin de evitar catalogarlo como un arte incongruente, insustancial. Significa apelar a la dialógica del conocimiento que posibilita trascender la interpretación de la lógica bipolar que concibe la realidad mediante la relación antagonista y excluyente de los opuestos, inherente al paradigma de la simplificación ; incapaz de imaginar la unión de lo uno y lo múltiple, ya que, "O unifica abstractamente anulando la diversidad o yuxtapone la diversidad sin concebir la unidad" (MORIN, $2005: 23,30,100$ ). Esta forma de racionalidad expresa la manera en que opera el paradigma de la simplificación, desarrollado por la tradición del pensamiento occidental.

Contraria a esta racionalidad, el pensamiento complejo, aborda el análisis fenoménico de la realidad en función de la existencia de lógicas aparentemente contrapuestas, pero mutuamente necesarias que se rigen por el principio dialógico, definido como la asociación compleja (complementaria/concurrente/antagonista) de instancias, necesarias, conjuntamente necesarias para la existencia, el funcionamiento y el desarrollo de un fenómeno organizado. De acuerdo con este principio de unidad, la dialógica actúa en todos los niveles de organización de los procesos vitales del universo (MORIN, 2009). Asume el carácter ambivalente de toda relación, reconociendo la coexistencia de dos términos, a la vez complementarios y antagónicos, de tal forma que "el principio dialógico nos permite mantener la dualidad en el seno de la unidad" (MORIN, 2005 :106) Conforme a estas premisas, la adopción de este principio de inteligibilidad posibilita la comprensión de fenómenos complejos inherentes a su condición dialógica.

4 La dialógica del conocimiento involucra asumir la indeterminación de toda realidad fenoménica regida por la interacción dialógica de conceptos como : organización/caos, sagrado/profano, puro/impuro, belleza/fealdad, tradición/modernidad, materia/idea, individuo/ sociedad, feminidad/masculinidad, lo cual coadyuva a la deconstrucción de la lógica bipolar, maniquea y determinista.

5 El discurso de la transgresión en las artes visuales plantea por lo tanto, el binomio transgresión/renovación con base en el reconocimiento de su unidad dialógica. De acuerdo con esta noción, la transición hacia nuevos paradigmas artísticos se finca en la abolición de los valores e ideales que en su momento histórico respondieron a las aspiraciones de una sociedad, lo mismo que a sus contradicciones internas. Así mediante avances y retrocesos, éstos se transforman, conforme a la interacción dialógica que plantea el derrocamiento del viejo paradigma y el establecimiento del nuevo, como lo demostraron las vanguardias artísticas de la primera mitad del siglo XX, cuyo espíritu revolucionario, rebelde, crítico y renovador propició el surgimiento de movimientos, estéticas y expresiones artísticas disidentes y transgresoras. "Desde Marcel Duchamp hasta fines del siglo pasado una constante de la práctica artística fue la transgresión” (GARCÍA, 2011 :15).

6 Tal es el poder transgresor del/la artista que logra, cuando tiene la virtud, las facultades y el talento, de asombrar, deconstruir, subvertir; y en suma, oponerse al statu quo y enriquecer la conciencia colectiva. En este sentido, "Las transgresiones suponen la existencia de estructuras que oprimen y de narrativas que las justifican" (GARCÍA, 2011 :17). En eso consiste el arte de la transgresión, en desactivar los paradigmas dominantes para dar paso a la realización de la utopía. 
7 Heredero de esta actitud subversiva e irreverente, el arte conceptual ${ }^{4}$ deviene conspicuo y deconstructor, en tanto que desmantela los cimientos, conceptos, definiciones y presupuestos del arte. Eliminar los límites tradicionales del arte es la consigna. El desplazamiento del objeto por la idea es la propuesta ; se enfatiza el proceso, el concepto o idea por encima de la realización material de la obra. "La idea se convierte en una máquina que produce arte" (SOL LEWITT apud MARCHÁN, 1990 :250). En adelante, la creatividad del/la artista se pondrá de manifiesto al concebir obras sui géneris que involucran una gran diversidad de recursos conceptuales que posibilitan la construcción de narraciones complejas dotadas de retóricas polisémicas.

\section{El contexto mexicano}

8 En México, los antecedentes del arte conceptual se remontan a finales de la década de los sesenta con las exposiciones del Salón Independiente (1968, 1969, 1970), donde se exhibieron ambientaciones y propuestas estéticas no convencionales. Como pionero de los happenings y del arte efímero, el representante indiscutible fue Alejandro Jodorowsky, multifacético teatrista, cineasta y escritor chileno, "sus planteamientos teatrales y artísticos influyeron de manera relevante en el ámbito de la cultura mexicana" (B. SÁNCHEZ 2003 :50). El artista rememora :

Yo sólo estaba siendo precursor de un arte que era del performance, en ese entonces llamado happening; sólo estaba inventando el poster, la minifalda, la canción de protesta, el arte colectivo. Todo eso se hizo en México antes que en Estados Unidos. Estaba transformando el teatro mexicano, pero los granaderos echaban ácido en las sillas. (...) Lo que se dio fue la ley del arte nuevo. Se hace el arte por la necesidad de abrir el espíritu y la sociedad se paralizan ante lo nuevo (B. SÁNCHEZ, 2003 :51).

El relato de la experiencia que tuvo en la televisión, cuando se presentó con un efímero pánico, resulta elocuente del impacto que causó :

El primer efímero que hice fue en la televisión; [...] Nos dieron una hora ; yo dije : 'vamos a hacer arte sagrado: el toreo es arte sagrado, el torero usa su instrumento, hace una obra de arte, y después destroza al toro ; yo voy a tomar un piano, lo voy a tocar y después lo voy a destrozar'. Tomé un martillo, toqué el piano, y después lo destrocé [...] Comenzó a telefonear la gente, llamó el ministro de Educación, todo el mundo me vio rompiendo el piano, fue una escandalera. Después lo hizo Dalí, pero yo fui el primero en romper un piano (MARTÍNEZ, 1998 :2).

10 Dos figuras merecen especial atención, ya que su destacada presencia a finales de la década de los sesenta resulta conspicua por sus propuestas no convencionales, ellos son Felipe Ehrenberg y Marcos Kurtycz. El primero, fue uno de los primeros artistas en realizar arte conceptual, ambientaciones y performances adaptados al medio mexicano (EDER, 1980 :379). El segundo, efectuó innumerables exposiciones donde abordó el arte correo, los libros de artista, la instalación o el performance. En opinión del crítico de arte Juan Acha: "El verdadero representante de los performances fue Marcus Kurtysze" (ACHA, 1993 :177). A través de sus obras, ambos artistas demostraron su desbordante imaginación y talento, dotando de originalidad al arte conceptual de esta época.

11 Sin duda, la década de los setenta quedó marcada por el surgimiento del arte social, "mediante una eficaz puesta en práctica de la corriente conceptualista alimentada con presupuestos semióticos", desarrollada por los Grupos de Trabajo Colectivo (DEL CONDE, 1994 : 46). Los Grupos estuvieron conformados por un importante número de artistas plásticos, jóvenes y experimentados, así como por críticos de arte, fotógrafos, 
diseñadores, historiadores, filósofos, cineastas, sociólogos, críticos de teatro, etcétera. Conformaron lo que suele denominarse de manera genérica como los Grupos : Tepito Arte Acá, Grupo Proceso Pentágono, Mira, Suma, Taller Arte e Ideología, Taller de Investigación Plástica, El Colectivo, Germinal, Fotógrafos Independientes, Peyote y la Compañía, Março, No Grupo, El Taco de la Perra Brava. En opinión de Alma B. Sánchez :

Su irrupción en el panorama artístico mexicano rompió inercias y consolidó expectativas novedosas en la forma de hacer arte. (...) Los Grupos confirmarían el ejercicio de un arte conceptual referido a las temáticas sociales y al ámbito urbano. Todo ello, como señas de identidad del arte conceptual mexicano de este periodo que por mérito propio logró ganarse un lugar en los espacios institucionales de legitimación artística (2003:59).

Con estos antecedentes se reconoce la renovadora influencia que las estéticas conceptuales ejercieron en las futuras generaciones de artistas. La consolidación del arte no tradicional o no objetual -como también se nominó al arte conceptual-, sentó las bases que marcarían el devenir del arte contemporáneo en México.

\section{Feminismo y artes visuales}

13 El surgimiento de lo que ahora se conoce como el feminismo de nuevo tipo emergió en México en el inicio de la década de los setenta como respuesta a los cambios socioculturales gestados nacional e internacionalmente. Sus principales variantes fueron el agotamiento del modelo de desarrollo estabilizador, el surgimiento mundial de diversos movimientos "contraculturales", y la ebullición de nuevas ideas en el seno de las élites intelectuales y de la práctica de la izquierda en México (TUÑóN, 1997 :64-65). En el transcurso de esta década se crearon más de una docena de grupos con distintos objetivos, fuerza política y capacidad de convocatoria. A partir de distintas concepciones y corrientes político-ideológicas en su interior, todos ellos caracterizaron conceptualmente el Movimiento de Liberación en México.

Las premisas de este movimiento apelaron a un cambio de conciencia para impugnar el modelo hegemónico masculino que representa la dominación de un sexo hacia otro. Este cambio implica una reorganización de la sociedad tanto en lo político y sexual como en lo económico y social. Pero sobre todo, pone énfasis en el lema lo personal es político. Esto significa revolucionar la esfera de la vida privada a partir de la lucha política para transformar las estructuras sociales y revolucionar la esfera de la vida pública. La lucha estaba encaminada a transformar la vida cotidiana y a debatir las relaciones hombre/ mujer más allá de las cuestiones, simplemente, de igualdad legal. Para lograr la igualdad de género, la batalla se debía dar en todos los campos en donde la dominación es más patente : el hogar (la doble jornada de trabajo, violencia intrafamiliar, alienación del trabajo doméstico); la calle (violación, violencia, prostitución); el trabajo (menor remuneración a igual jornada de trabajo, acoso sexual); los medios de comunicación masiva (degradación de la identidad femenina, creación de estereotipos femeninos, mujer objeto, consumista, etcétera); la discriminación legal (despenalización del aborto, divorcio, adulterio) la sexualidad (derecho al placer femenino, ejercicio de la sexualidad sin fines reproductivos). Esto se traduciría en la recuperación y vindicación de la mujer como ser humano en todos los aspectos de su vida y como una liberación sexual, doméstica, etcétera. 
15 La indiscutible influencia del movimiento feminista en la conformación de una nueva cultura femenina contribuyó a despertar conciencia de género en algunas mujeres artistas que dentro o fuera de la militancia comenzaron a plantear temáticas de esta índole en su discurso visual. Sin embargo, la teorización sobre arte y feminismo no estuvo contemplada dentro de los debates ideológicos de los diversos grupos. De ahí que no exista una vinculación directa entre la emergencia del arte feminista y el movimiento. Si bien la década de los setenta marcó el surgimiento de una nueva cultura femenina, la irrupción de las artistas feministas tanto individuales como grupales, no se derivó como consecuencia de la relación entre el movimiento feminista, sino, debido a las inicitivas de auto organización de algunas creadoras para plantear vindicaciones de género en el ámbito de las artes visuales.

16 El surgimiento del arte feminista en México obedeció, entre otros, a los siguientes factores : a) la coyuntura sociocultural abierta por el movimiento de liberación femenina y la difusión de los valores feministas, sobre todo la influencia del feminismo norteamericano; b) la celebración del Año Internacional de la Mujer en 1975 ; c) la creación del taller de arte feminista, impartido por Mónica Mayer en la Academia de San Carlos (ENAP-UNAM., 1983-1984).

17 A pesar de que existió contacto entre las artistas feministas y algunos de los grupos del movimiento de liberación de la mujer a partir de su mutua participación en mítines, congresos, mesas redondas, conferencias, etcétera, en los que éstas colaboraban en la parte plástica con exposiciones o eventos, no se logró consolidar el apoyo del movimiento hacia la causa de artistas feministas. Al respecto, Magali Lara opina lo siguiente :

De hecho yo creo que las artes plásticas nunca tuvieron un buen vínculo con la parte feminista teórica, que aunque son gente muy padre, gente que le gusta el arte, por alguna razón hicimos varios intentos y nunca hubo una relación. Yo me imagino que porque nunca hubo alguien que escribiera sobre arte y que participara en esos lugares. No hubo este puente, nosotras tuvimos en los grupos con Mónica Mayer, Rowena Morales, Carla Rippey, Yolanda Andrade, algunos contactos con la revista Fem, se llegó a plantear inclusive que hiciéramos algunas portadas, Rowena creo que hizo una, yo hice dos, pero nunca hubo un real eslabón entre estas dos cosas, de tal manera que yo siento que a estos años de distancia la revista de Debate Feminista, si tu te fijas lo que tiene de artes plásticas es mínimo, se sigue notando ese silencio (LARA, 1998).

Varias son las razones que estas artistas han esgrimido en torno de dicha situación. Una de ellas es el carácter antisolemne e irreverente que adoptaban sus eventos, cuyo discurso visual consideraba los temas más escabrosos de la condición femenina a partir del humor y la ironía. Propuesta que desde el punto de vista de la militancia feminista resultaba poco seria. Además de que las feministas estaban muy desvinculadas del ámbito de las artes visuales y de la problemática de la condición de las mujeres artistas, pero sobre todo, eran ajenas a los procesos plásticos contemporáneos y estaban desinformadas acerca de las propuestas artísticas de las artistas feministas, como los lenguajes conceptuales y las estéticas no tradicionales, conforme al testimonio de Ana Victoria Jiménez :

Era muy crítico lo que estábamos haciendo, al grado que las feministas, ni le entendieron ni le entraron, ni para beneficio ni para perjuicio, ni criticaron esto (...) El feminismo yo creo que si le preguntas al noventa por ciento de las feministas no saben que existieron los grupos, porque además la historia del feminismo está perdida y está dispersa, cada quien platica de lo que ha vivido ¿no ?, pero así que diga alguien que haya podido compendiar la historia global del feminismo en todos los aspectos, no hay. Mónica, yo, y otras teníamos buenas relaciones, yo milité en el 
primer MAS, he estado en muchos grupos, en todos lo grupos de conciencia que en esa época se formaron, pero luego estuve en el Movimiento Nacional de Mujeres, o sea, he estado en muchos grupos que han hecho actividad importante y destacada, estuvimos en la Coalición de mujeres feministas, incluso Mónica empezó su primer taller de arte feminista con la finalidad de que las feministas se vincularan con el arte en la Coalición de mujeres, ella iba todos los sábados se plantaba ahí en la oficina de la Coalición, ponía su letrero toda la semana, decía taller de arte feminista. ¿Tú crees que alguien fue a un curso o a darse una idea de qué ? Nada, o sea que el arte no les interesaba, aparentemente. Aunque no había ya muchas artistas en ese momento. En los primeros grupos feministas sí había artistas, incluso el primer poster sobre el feminismo lo hizo Leonora Carrington, fue el primer poster que tuvo el feminismo en México (JIMÉNEZ, 1999).

19 En esta perspectiva, la conciencia crítica feminista en el arte comienza cuando las mujeres artistas se asumen como creadoras militantes con todas las implicaciones que esto conlleva. Una postura política que se expresa a través de su arte para impugnar de manera frontal y directa los valores de género de la cultura dominante.

\section{Poéticas transgresoras en la plástica femenina de los 70 s y 80 s.}

Una vez afirmados los lenguajes conceptuales, se constituyeron el medio idóneo para que las artistas se expresaran mediante poéticas inéditas. Así, a finales de la década de los setenta, en el panorama de la plástica de mujeres, emergió un incipiente discurso visual que evidenció una nueva conciencia femenina manifestada en la realización de obras con temáticas que habían resultado tabú como la sexualidad y el erotismo femeninos. ${ }^{5}$ Superarlo significó un reto para la época, lo cual representó una audacia que muy pocas se permitieron. De ahí el valor que adquieren las obras de aquellas que se atrevieron, a subvertir la representación femenina en el arte de mujeres, pues marcó los antecedentes de un arte contemporáneo de mujeres sin autocensura.

Entre las artistas que destacan se encuentra Magali Lara cuya trayectoria es amplia dentro de las artes visuales en México y el extranjero, formó parte del Grupo Março que realizaba arte urbano. Se ha destacado en la pintura, la fotografía, además de utilizar el collage y otros materiales considerados entonces como alternativos para la elaboración de sus obras. También aborda el arte correo, arte objeto y libros de artista.

Magali Lara desafió la censura al abordar con audacia el tema de la sexualidad femenina : no se esperaba que una mujer lo tocara por considerarse tabú, como lo testimonia la propia artista :

A mí me interesaba esta parte de la mujer, me interesaba este trabajo que tenía que ver con la sexualidad y con los sentimientos y que no estaba permitido, era un tema de mal gusto en ese entonces. (...) Mis temas eran eróticos y recibí muchas críticas. (...) Yo tuve una respuesta tremenda, la gente me escribía puta. (...) No se esperaba que se pintaran esas cosas. Una chava que se atreviera haciendo eso no se esperaba. Mi generación quería hacer algo diferente. (...) Mi exposición fue muy agresiva porque hablaba de coger y yo era una chava y supuestamente era un tema de mal gusto. Existía la consigna de que era de mal gusto. En esa época Frida Kahlo no era famosa todo mundo decía pinche Frida siempre con la sangre y esas cosas tan feas. Para nosotras era importante (VÁZQUEZ, 1994 :s/p). ocasiones llegaron hasta agredir la obra. Ejemplo de ello fue lo sucedido en la exposición 
que en 1975 realizara Mónica Mayer, quien como estudiante de la carrera de artes plásticas en la Escuela Nacional de Artes Plásticas de la UNAM presentó en la Academia de San Carlos una serie de fotocollages eróticos que fueron agredidos, como lo confirma la artista: "En esta exposición colgaron todos mis cuadros de cabeza y el público los rompió...” (VÁZQUEZ, 1994 :s/p).

Maris Bustamante es otra de las artistas que perteneció a la generación de los Grupos. Trabajó con el No Grupo, desde su fundación en 1979 hasta su desintegración seis años después. En su experiencia como artista visual, Bustamante ha realizado exhibiciones individuales $\mathrm{y}$ ha participado en exposiciones colectivas, tanto nacionales como extranjeras. Además de haber incursionado en todas las disciplinas artísticas tradicionales como dibujo, pintura, mural, grabado, se inclinó por los soportes no tradicionales, realizando performances, instalaciones y ambientaciones, así como contraespectáculos.

A principios de la década de los ochenta desafió los convencionalismos temáticos de la obra realizada por mujeres al abordar el tema de sexualidad, el erotismo y la pornografía. Cabe mencionar el performance llevado a cabo en el Museo de Arte Moderno de la Ciudad de México en 1982, que llevó como título ¡Caliente-caliente! En su narración visual, la artista cuestionó con hilarante humor y sarcasmo los postulados psicoanalíticos de la envidia del pene elaborados por Sigmund Freud.

El interés mostrado por las creadoras sobre nuevas temáticas se manifestó a través de su colaboración. Ejemplo de ello fue el evento que, con el título de Montaje de momentos plásticos, se celebrara paralelamente a la exposición La creación femenina, efectuada en el auditorio del Instituto Goethe de México, D.F, en 1980, y que a su vez fue un intercambio cultural entre México y Berlín. En este evento Maris Bustamante y Magali Lara, realizaron un performance, cuyo tema era el código erótico femenino.

La inquietud de las artistas por abordar la sexualidad femenina se repitió en otras exposiciones. Otro ejemplo, lo constituyó la instalación colectiva que realizaron en 1982 Magali Lara, Rowena Morales, Maris Bustamante, Adriana Slemenson y Mónica Mayer como participantes del Foro de la Mujer en el Festival de Oposición, organizado por el Partido Socialista Unificado de México (PSUM). Las artistas realizaron una instalación en la que cada una de ellas elaboró su propia narración acerca de la sexualidad.

Rowena Morales es otra representante de la generación de los Grupos, estuvo incluida en el grupo Proceso pentágono. En su obra, Morales también manifestó su interés por el género. Realizó estudios de artes visuales en la Escuela Nacional de Artes Plásticas, a la vez que ha consolidado su trayectoria artística gracias a exposiciones individuales y colectivas, tanto nacionales como extranjeras. Incursionó en el diseño de joyería y en las disciplinas artísticas del dibujo y la pintura.

En la exposición Historias paralelas. Paralelos en la historia, realizada simultáneamente con el artista Carlos Aguirre en el Museo de Arte Moderno en 1985, Morales desarrolló el tema de la sexualidad femenina. Sobre esta exposición la artista comenta su propuesta : :

Pensamos que era interesante que el espectador viera dos exposiciones diferentes en el tema, pero dentro de una misma tendencia narrativa y visual. Yo hablo de la historia de todos los días que vive la mujer y exploro en diversas técnicas de expresión 'no ortodoxas' en la pintura, como : cosidos, encajes, bordados, botones que pertenecen a una iconografía femenina. (...) Considero que el desarrollo de la sexualidad femenina ha sido muy conflictivo; en mis cuadros ubico el cuerpo femenino para ir narrando este desarrollo donde la mujer no se puede expresar 
afectivamente sin ser mal vista. Retomo objetos que utilizamos en el contexto doméstico como agujas, bastidores de costura, botones y telas, no para continuar alienando a la mujer en este ámbito sino para transformar estos elementos y hacer que trasciendan en la sociedad (ABELLEYRA, $1985: \mathrm{s} / \mathrm{p}$.).

En este contexto se puede exaltar el mérito cultural y artístico de las artistas que abordaron temáticas que resultaban tabú para la época, ya que a través de la transgresión de sus discursos visuales subvirtieron la representación de la identidad femenina construida por la mirada de la cultura patriarcal que la exhibe como un ente pasivo, objeto del deseo masculino, al que no se le concede el ejercicio de un erotismo y sexualidad autónomos. Ergo, la autorepresentación de la subjetividad femenina que la muestra a partir de una mirada propia, que exalta el poder latente de su erotismo y sexualidad deconstruye esa mirada. Tal es el valor del gesto, la osadía, del/la artista que en su momento histórico, se atreve a ir más allá, al traspasar y romper los límites que éste le impone.

Es importante destacar que en este momento las artistas no se estaban planteando vindicaciones feministas a través de su obra. No obstante, que en sus discursos visuales subvirtieran el rol de género impuesto por la representación hegemónica. Y hasta puede decirse que no buscaban ser identificadas como creadoras comprometidas con el feminismo, ya sea porque su ideología no se los permitió, o bien porque las militantes feministas al cuestionar los valores de género de la cultura patriarcal, enfrentaron una campaña de desprestigio que las consideró transgresoras al orden establecido. De modo que, ser identificada como feminista, equivalía a un calificativo peyorativo o era sinónimo de androfobia . Razón por la cual muchas mujeres rehuían ser estigmatizadas, estereotipadas o segregadas. Por tanto, se puede hablar de narraciones provocadoras, transgresoras al statu quo de la cultura visual dominante, más que de Arte Feminista con todo lo que ello conlleva.

\section{Obras feministas, el discurso políticamente "incorrecto"}

32 A finales de la década de los setenta surge un arte cuya propuesta se centra en un nuevo contenido temático : el feminismo. La conciencia crítica feminista en el arte inicia cuando las creadoras se asumen como artistas feministas. En las artes visuales algunas reaccionaron al proceso de difusión de las ideas feministas con el fin de emprender una discusión acerca del estado de las mujeres artistas y la creación de un arte político feminista.

33 Mónica Mayer fue una de las artistas que a partir de su experiencia como estudiante de la Academia de San Carlos, manifestó su interés por la cultura femenina, este afán la llevó a involucrarse con el movimiento de liberación de la mujer donde gestó su ideología feminista. ${ }^{6}$ Derivada de su experiencia como militante, decidió integrar sus planteamientos feministas en la plástica, este es su testimonio :

En esa época me empezaba a picar el gusanito del feminismo por algunas situaciones que me hicieron percatarme que, en efecto, había tal cosa como sexismo. Un ejemplo fue durante una clase en la que la discusión acalorada sobre el tema de la mujer en el arte llevó a nuestros compañeros varones (ante el asombro de quienes siempre nos habíamos considerado como iguales) a afirmar que la creatividad de las mujeres era inferior por el hecho de que podíamos tener hijos. Con ese antecedente, al leer Artes Visuales salí directo al MAM y me le presenté a 
Carla Stellweg para solicitarle la dirección de estas mujeres que acababan de abrir una escuela de arte feminista en Los Ángeles (...) (MAYER, 1995 : 2). Lago de la Ciudad de México, organizada por Rosalba Huerta, Lucy Santiago y Mónica Mayer, para ese entonces ya autodefinidas como artistas feministas. Se llamó Collage intimo y exhibieron trabajo que hablaba de su experiencia como mujeres.

Sobre esta exposición es importante señalar la identificación ideológica de las tres artistas y su afán de colaboración con el propósito de convertir las voces individuales en una voz colectiva. Asimismo, destaca el hecho de que por primera vez se presentó en México, una propuesta creativa de arte vaginal.

Mónica Mayer relata esta experiencia :

Recibíamos al público con este cuadro mío llamado "A Veces me dan miedo mis pensamientos, mis fantasías.", que son las palabras escritas en el cuadro. La gente entraba, abría la cortina y veía ésta (sic) imagen (MAYER 1979-1980 : s/p.).

Mónica Mayer, A veces me dan miedo mis pensamientos, mis fantasías

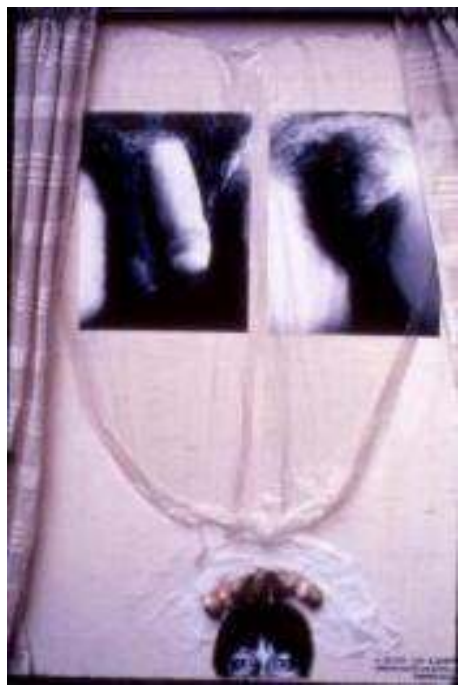

Técnica mixta, Casa del Lago, México, D.F., 1977.

Fotografía Mónica Mayer

Cabe destacar la presencia de Nunik Sauret, quien se caracterizó por el tratamiento de temas eróticos en su obra. Su formación académica se ubica en la Escuela Nacional de Pintura y Escultura La Esmeralda y el Taller de Grabado Molino de Santo Domingo. La artista comenta lo que le implicaba el tratamiento de sus poéticas visuales :

(...) Al principio cuando llevaba mi obra a las galerías me criticaban que lo que yo hacía era más apropiado para un hombre. La gente sigue creyendo que las mujeres debemos hacer florecitas y paisajes y ya basta de pensar que debemos ser empalagosas. De unos 10 años a la fecha me he interesado por la germinación, la vida, la naturaleza, la fuerza femenina, sobre todo en este momento de la mujer que está resurgiendo, interesándose por su parte íntima, reivindicando muchas energías ocultas, dormidas. Yo me aboco a mi cuerpo y al de las mujeres en general porque por lo regular se ha tratado sólo por hombres; es reciente el que poetas, bailarinas, actrices se han puesto a expresar lo que sienten dentro de su cuerpo, a hablar de él desde el punto de vista femenino. Para mí el tema mujer es una necesidad interior que tenía que sacudir, y encontré la técnica para expresarla y transmitir a las otras mujeres para ir creando la conciencia a través del arte. Intuitivamente con una obra 
se captan muchas cosas y yo lo he visto con el público, las mujeres sienten algo dentro que las conmueve, aunque, claro mi obra se dirige a todo público, pues hay que hacer consiente también al hombre, es importante hacerle sentir ese mundo interno que estamos descubriendo y mostrando las mujeres. Me interesa mucho la ruptura, que rompamos con los convencionalismos establecidos por una sociedad machista que nos adjudica un papel estrecho del cual es difícil salir. A partir del cuerpo físico entré a mi mente para parirme a mí misma, como el nacimiento de otra mujer (SESÍN, $1986: \mathrm{s} / \mathrm{p}$ ).

Es un hecho que estas propuestas devinieron políticamente incorrectas, toda vez que resultaban inéditas en la plástica femenina de la época, pero sobre todo porque deconstruían los valores de género de la cultura visual en el patriarcado. En este sentido, el Arte Feminista se evidencia como transgresor por antonomasia.

De aquí en adelante, algunas artistas mostrarán un enfoque radicalmente feminista con el planteamiento de temas como el aborto, la violación, la contracepción, la doble jornada de trabajo, la maternidad, etcétera. El interés de aquéllas será un arte feminista con carácter de denuncia vinculado a la causa de las mujeres.

Otra experiencia de trabajo colectivo fue la exposición de Arte Feminista Lo normal, celebrada en 1978 en la galería del Consejo Nacional de Recursos para Atención de la Juventud. En esta exposición, Mayer montó una instalación con el objetivo de que la gente reflexionara acerca de lo que la sociedad consideraba normal en el ámbito de la sexualidad.

La autora explica su propuesta :

Yo tenía una serie de tarjetas postales satirizando los cuestionarios psicológicos en las revistas femeninas sobre sexo. Cada tarjeta tenía diez expresiones diferentes, desde alegría hasta horror. Las tarjetas decían: "Quiero hacer el amor" y después mencionaban diez diferentes posibilidades que por lo general se consideran tabú en nuestra sociedad. El público trazaba un círculo en la expresión que se acercaba más a su reacción, sumaban el resultado y encontraban que a nadie que le gustara nada podía ser normal (MAYER, 79-80:s/p).

42 Ese mismo año se reunieron las artistas Ana Victoria Jiménez, Rosalba Huerta, Esperanza Baldera, Yolanda Andrade, Carolia Paniagua y Mónica Mayer, para conversar acerca del arte militante. Esta experiencia colectiva dio como resultado la exposición Arte feminista presentada en la Galería Contraste de la Ciudad de México.

3 Entusiasmada por el Arte Feminista, Mónica Mayer decidió viajar a los Estados Unidos para estudiar en el Feminist Studio Workshop, de Los Ángeles, California. Durante su estancia, entre 1978 y 1980, Mayer asistió a diversos cursos de Arte Feminista, como Drawing, con Nancy Buchanan ; Sculpture, con Bruria ; y Critique, con Arlene Raven, todos en el Womans's Building. También participó en diversas exposiciones colectivas. Una vez terminados sus estudios el año de 1980, obtuvo la maestría en sociología del arte en la Universidad de Goddard, Estados Unidos, con la tesis Feminist Art: An Effective Political Tool.

44 Una de las exposiciones que Mayer realizó el año de 1980, merece especial atención por la audacia irreverente de su temática. Se denominó Silencios, vírgenes y otros temas feministas, inaugurada en el Instituto Anglo Mexicano de Cultura de la ciudad de México.

45 En esta ocasión, Mayer utilizó el icono de la Virgen para realizar un cuestionamiento en términos feministas acerca de esta imagen religiosa. En la exposición la artista presentó varias obras que fueron censuradas por los organizadores -de acuerdo con el testimonio de la propia artista- (MAYER, 1997). 

fotocopia la imagen de una caja de limosnas de las que hay en las iglesias, con el rostro de la Virgen de la Dolorosa pegado en la parte frontal, y el símbolo de la cruz cristiana en color rojo, enmarcando la imagen. Varios trazos que se conectan con las extremidades de la cruz aluden implícitamente a la suástica nazi, la palabra en inglés jrape!-que traducida al castellano significa "violar"- aparece en la parte inferior y se repite al igual que la imagen hasta formar un collage en donde el icono de la Virgen termina roto. sugerencia a una reflexión y una lectura feminista que transgrede los límites de la representación al cuestionar la imagen de la Virgen consignada por la religión cristiana, a la vez que una provocación para romper el silencio y desafiar el tabú religioso, a saber : los símbolos sagrados son intocables e incuestionables.

Desde el título de la exposición, Mónica Mayer hace explícito su afán de subvertir la carga simbólica que representa este arquetipo dentro de la teología patriarcal cristiana. Al respecto, Mayer expresó que para elaborar su discurso conceptual, había utilizado una caja de limosnas como las que se encuentran en las iglesias relacionándola con los símbolos de la Virgen y de la cruz cristiana, para aludir a la suástica nazi (MAYER, 1999), porque :

(...) para mí todas las creencias se me hacen muy nefastas. La suástica no es tan evidente, porque si no llega Pro-Vida y me mata. Las creencias ciegas pasan a fregar a la mujer, imponen una forma de ser diferente, basada en una moral sexual fascista. Relacioné la cruz con el falo, el color rojo con la violencia, la sangre, el dolor, de ahí la palabra "rape" - .

\section{Mónica Mayer, Silencios, vírgenes y otros temas feministas}

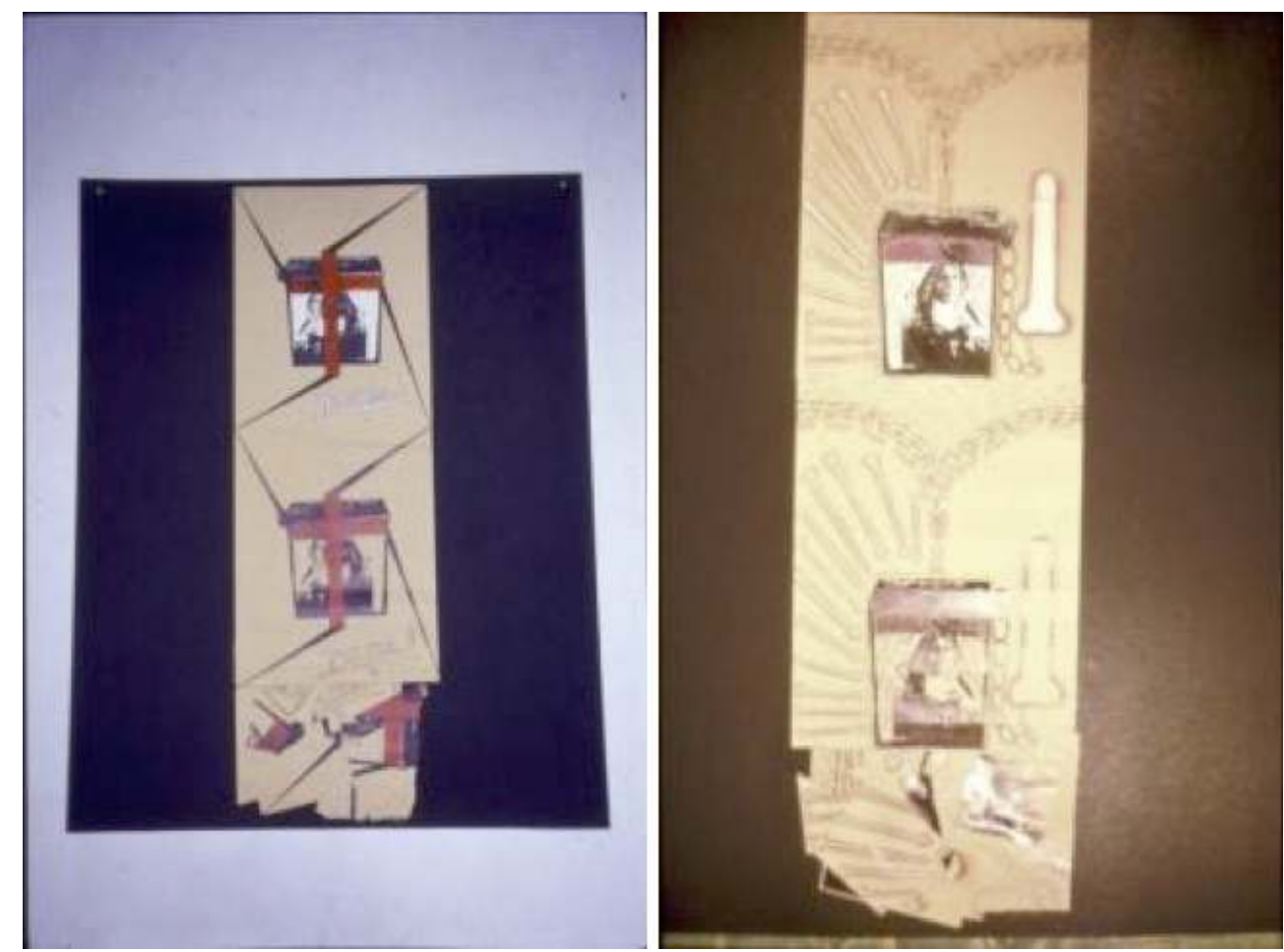

Técnica mixta, Instituto Anglo Mexicano de Cultura, México, D.F., 1980.

Cortesía de la artista. 
Mónica Mayer, Nuestra Señora de la Opresión

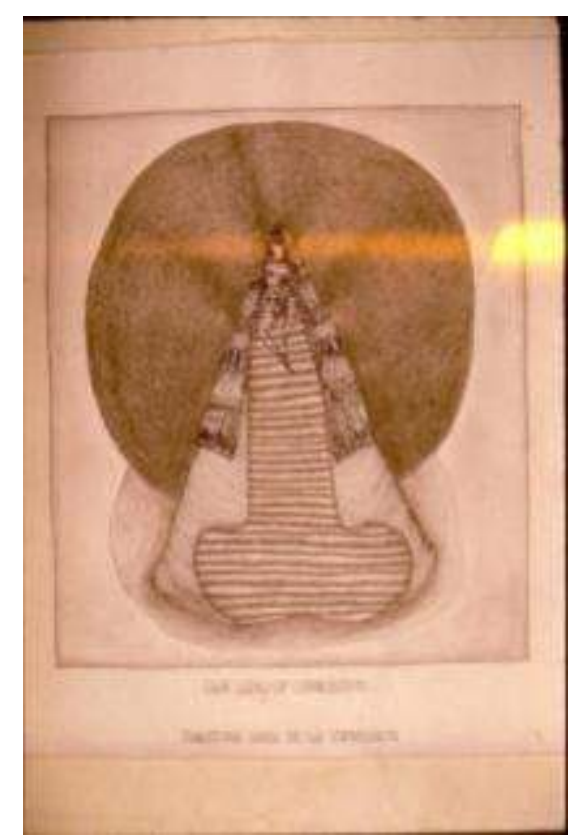

Estampa, Instituto Anglo Mexicano de Cultura, México, D.F., 1980.

Cortesía de la artista.

Desde la perspectiva crítica del Arte Feminista la lectura del texto visual de Mayer, se interpreta como alegoría contra la represión sexual imputada por la moral de la religión cristiana. Acaso uno de los rasgos significativos de esta teología sea la sexofobia, enérgico rechazo a cualquier manifestación erótica. Desde un principio, en el seno de la Iglesia cristiana, y bajo la enseñanza patrística, se infería el concepto del sexo como pecado por antonomasia. En el interior de esta tradición el mito teológico de la concepción refuerza el tabú de la sexualidad femenina, representado en la figura de la Virgen María, cuyo cuerpo es escindido de toda manifestación erótica y transformado en un recipiente, un espacio sagrado. En la mitología cristiana el cuerpo de María se fragmenta: es sólo vientre, matriz "...de tu vientre, Jesús"; sus senos son fuente de alimento, dejan de ser parte de su eros, la vulva, la vagina y el clítoris son órganos innombrables, ocultos, en tanto que no intervienen en el misterio de la concepción, pues María concibe sin varón "por obra y gracia del Espíritu Santo". María es virgen, núbil, es en realidad, la «nomujer », la mujer « desexualizada », la que fue concebida y concibió a su vez sin pecado. El erotismo de la Virgen es negado, ausente, y concreta el veto social del erotismo femenino. El mito relata simbólicamente la mutilación de la Virgen y en ella, la de todas las mujeres (LAGARDE, 1993 :205, 315).

La valoración negativa de la mujer, intrínseca a la concepción cristiana del mundo y de la vida, se expresa en el estigma inherente a su condición sexual : la menstruación es la marca en el cuerpo de las mujeres del rechazo social al cual están sometidas, de su descalificación y sojuzgamiento ; es decir, su opresión justificada en la suciedad de sus cuerpos sangrantes e indignos, (LAGARDE, 1993 :319), como lo testimonian los textos sagrados, que consideran impura tanto a la mujer recién parida como a la mujer menstruante. 

1993 :204).

Por ello, el mito de la concepción consigna y consagra el tabú : el cuerpo embarazado de la mujer es signo y símbolo de la negación del erotismo humano, en especial del femenino. "Se trata de su valoración negativa, con el fin de constreñirlo, de normarlo con una finalidad determinada : afirmar la castidad como esencia erótica de las mujeres y su cuerpo como espacio con-sagrado a la gestación" (LAGARDE, 1993 :204).

De esta manera María queda excluida del estigma de la sexualidad que la develaría esencialmente humana en su aspecto negativo, o sea, el pecado :

Uno de los significados implícitos de este mito, la humanidad de María, símbolo de la mujer y de las mujeres, queda centrado en su sexualidad erótica, la cual le es conculcada de manera simbólica, como había sido conculcada en la historia a las mujeres. El mito no miente, ni propone algo increíble, sólo purifica a María y la convierte en este estereotipo de identidad femenina. Al negar el hecho divino, el mito minimiza el hecho humano y casi lo oculta. ¿Es que acaso en la realidad las mujeres son eróticas, son sujetos del goce, existe su cuerpo como espacio del placer? No, la respuesta es no. Las mujeres no gozan, las mujeres buenas son como María (LAGARDE, 1993 :204).

En este orden de ideas el ideal femenino de la religión cristiana girará en torno al culto del símbolo de la Virgen, de la mujer desexualizada, casta, virgen, continente, temperante y abstinente; de la madre dolorosa, abnegada, inmaculada, que mientras más sufra y se resigne a su destino, esto es, a su condición femenina, en mayor medida será glorificada por la cultura patriarcal :

En este marco, las mujeres son vírgenes, aunque cojan : no gozan su cuerpo ni el del otro, participan del coito de otro, no en el coito ; lo sufren, obedecen y cumplen como un deber que, por otra parte el matrimonio santifica, pero con la finalidad implícita de tener hijos, de procrear. Eso sí, "los hijos que Dios quiera. (LAGARDE,

En este tenor, el texto visual de Mayer se descifra como una enérgica crítica a la religión cristiana, como un repudio a las ideas e imágenes que esta teología ha elaborado sobre la mujer mediante la alegoría del rompimiento del icono de la Virgen, a la vez que alude a la cruz como símbolo de la teología fálica, con todas las connotaciones que esta representación implica, como el desdén de la religión al erotismo y en especial a la sexualidad femenina, el requisito de la virginidad, la sumisión, la resignación, el sufrimiento, y por lo tanto, la sacralización e imposición de estereotipos femeninos basados en estos atributos simbólicos.

Vale señalar que los organizadores de la exposición no ofrecieron a Mayer ninguna explicación sobre la censura de algunas de sus obras, pero se infiere que lo hicieron por prejuicios religiosos al considerar que la artista atentaba contra un símbolo sagrado de la tradición cristiana, intocable y por ende incuestionable. ${ }^{8}$

Desde un principio, el objetivo de Mayer fue iniciar un movimiento de Arte Feminista en México, como ella misma lo consigna :

Desde que vine a estudiar al Woman's Building (un centro para la cultura de las mujeres) en Los Ángeles en 1978, mi mayor deseo ha sido llevar la información que he encontrado aquí a mi país, México, y extender nuestro movimiento de arte feminista (MAYER, 1979-1980 : s/p).

La experiencia que Mayer obtuvo de su trabajo en los Estados Unidos, en armonía con las condiciones creadas por el movimiento de liberación femenina, fue determinante para que de regreso a México difundiera y fomentara el Arte Feminista, con plena conciencia de lo que ello representaba, a saber, un arte en donde se asumieran como artistas feministas 
para impugnar la opresión de la mujer con una propuesta artístico-feminista. Así a principios de la década de los ochenta surgieron los autodenominados grupos de artistas feministas: Tlacuilas y Retrateras, Polvo de Gallina Negra y Bio-Arte, integrados el año de $1983 .{ }^{9}$ Constituyen un caso inédito dentro del contexto del arte de mujeres en México, que implicó la autoorganización e identificación de las productoras artistas entre sí, mediante su adscripción a una misma ideología : el feminismo.

Acorde con el espíritu cultural de la época, su propuesta plástica consistió en iniciar el debate acerca de las bases políticas e ideológicas de la creación cultural imperante, así como de impulsar la creación artística alternativa cuyo punto de partida se sustentó en la experiencia femenina en la sociedad patriarcal para denunciarla, confrontarla y vindicarla con su arte.

60 Cabe resaltar la riqueza de medios empleados por tales grupos para edificar sus discursos visuales, la versatilidad de sus integrantes se puso de manifiesto mediante el manejo de múltiples géneros como la gráfica, el arte correo, el dibujo, el collage, la pintura, la instalación, la ambientación, la fotografía, etcétera; no obstante, el género más recurrente fue el performance. Quizás por su carácter deconstructivo e intrínseco, el performance fue utilizado por las artistas feministas como una de las estrategias visuales más eficaces para subvertir el discurso hegemónico de la representación.

61 Lo importante es que deviene en un recurso ad hoc para promover los objetivos del feminismo, enfocado en desnaturalizar e interrogar los discursos preponderantes que sostienen que el poder/conocimiento es masculino; en este sentido, la estrategia feminista consiste en deconstruir dichos discursos por medio de técnicas desestabilizadoras para desestructurar el orden patriarcal. Jean Franco (1993:280) sostiene que "esta desestabilización se produce de diversas maneras, a través de la parodia y el pastiche, mediante la mezcla de géneros, o por la vía de la construcción de mitologías subversivas". Otra estrategia es aquella que vindica el derecho a la autorepresentación, convirtiendo a las mujeres en los sujetos hablantes del discurso. En opinión de Jeannie Forte (apud NEAD, 1998 :113) la representación interpretada por mujeres funciona como " una estrategia deconstructiva». Forte afirma que el discurso patriarcal depende de la construcción de las mujeres como objeto, como ese término del lenguaje del que siempre se habla, pero que nunca alcanza el estatuto de un sujeto que habla de verdad. Esto significa que las mujeres de verdad son hechas invisibles, una ausencia dentro de la cultura dominante, y sólo pueden hablar asumiendo la máscara de la falsedad o la simulación: "El arte interpretativo de las mujeres opera para desenmascarar esta función de la "Mujer", que responde al peso de la representación, creando una conciencia aguda de todo lo que significa Mujer, o feminidad". De esta manera el Arte Feminista se afirma como transgresor porque intenta contradecir la diferencia sexual dentro de la cultura patriarcal para subvertir las fronteras del género del discurso predominante de la representación.

\section{El legado : la transgresión del género}

62 El legado de las transgresiones estéticas que han nutrido al arte disidente, crítico, cuestionador al statu quo, se puede concebir como una lección histórica, que ha demostrado que la osadía e inteligencia de las mentes creadoras es una condición necesaria para transformar y sacudir la ortodoxia que impone el espíritu normalizador de la época. Derribar sus barreras, ha motivado el advenimiento de expresiones artísticas 
que en su momento han devenido deconstructoras, discrepantes, irreverentes, políticamente incorrectas, tal audacia, ha permitido dotar de significados culturales renovadores a las nuevas generaciones. Así se pueden contextualizar las estéticas heterodoxas que desde la década de los noventa en adelante expresan la inconformidad, la disonancia, para motivar el cambio y el tránsito hacia nuevos paradigmas.

Una vez que las artistas rompieron el tabú de plantear temáticas acerca del erotismo y de la sexualidad femenina, del cuestionamiento de los iconos religiosos ; así como de los roles de género dentro del patriarcado, entre otros, en adelante las creadoras harán patente su derecho a disentir de los valores de la cultura hegemónica, tal es el caso de Elizabeth Romero (1960), quien ha planteado la deconstrucción de la representación de la identidad femenina a través de sus obras. Artista visual, escritora, en su trayectoria artística, ha presentado obra objetual y no-objetual en exposiciones tanto individuales como colectivas en México, Argentina, Brasil, República Dominicana, Italia y Japón por citar algunas. Con más de 40 performances, ha trabajado desde el propio cuerpo como lugar de enunciación para construir el discurso de la autorepresentación de la subjetividad femenina.

Una obra que deviene deconstructora por la temática que aborda la representación simbólica de la feminidad asociada al imaginario de su genitalidad, así como a un acto de culto devocional guadalupano, se titula Cihuayo, realizada el 11 de diciembre de 2006 en el Taller de la autora, ciudad de México. Constituye una acción de estética ritual de intervención corporal en genitales.

De acuerdo con la descripción de Alfredo López Austin (1996:335), la palabra náhuatl cihuaáyotl, alude a la creencia en un líquido femenino correspondiente al semen. Mientras que Cihuatliacayo, Tepilcuaxicalli designan a la vagina, Cihuapilli. Nenetl. Cocoxqui. Tepilli. Omeiten refieren a vulva y vagina.

La autora sustentó su narrativa visual tomando como referencia la cosmovisión de los antiguos nahuas que en su aspecto ritual acostumbraban las mortificaciones del cuerpo. Afligían sus carnes, ya que obedecían la prescripción de los especialistas en magia, de la religión, o para fines rituales calendáricos. Con este objetivo, se practicaba el punzamiento de diversas partes del cuerpo para provocar sangrías, el ayuno general o de específicos alimentos, la abstención sexual, los períodos prolongados de vigilia o la interrupción del sueño, los baños en agua fría y la privación del pulque. La punción y la sangría se realizaban tanto para provocar dolor físico, como para obtener el líquido vital para ofrendarlo a los dioses.

La donación podía perseguir algún beneficio, y recibía por ello el nombre de "pago" (nextlahualli). Existía también la convicción que al ofrecer sangre se evitarían daños enviados por los dioses, canjeándose en esta forma la entrega voluntaria, espontánea, del plasma, por la seguridad. Cuando los maridos temían que las diosas cihuapipiltin perjudicaran en el parto a sus esposas embarazadas, se abrían sus párpados y debajo de su tetilla izquierda, el sitio más próximo al corazón, untan con la sangre tiras de papel, y quemaban la ofrenda ante las imágenes de las diosas solares. De este modo, rendían sacrificio. Otra de las finalidades era expiar por medio del sacrificio cruento los pecados que se habían cometido, y en esto tenía también importancia el sitio del cuerpo en el que se hacía la punción, con frecuencia el mismo que había servido para pecar (LÓPEZ, 1996 :438-439).

Elizabeth Romero (ENTREVISTA , 2009 :1) refiere que la acción se llevó a cabo por su deseo de colocarse un piercing en los genitales, por lo cual decide ritualizarla. Es lo que ella denomina una forma de ritualizar la vida personal, asimismo, consideraba que por medio 
de un acto de magia amorosa ; y a través del autosacrificio, la Virgen de Guadalupe le concedería su petición :

Yo me quería poner un piercing, ritualizar la intervención y hacer las dos cosas a la vez, es esta parte de ritualizar la cotidianidad, ya que me voy a poner el piercing lo ritualizo. Le pedimos cosas a las deidades para que nos las concedan. Si yo hago algo voy a provocar que la deidad me conceda algo (...) quería ofrendar sangre para que mi amado volviera, quería y no me lo concedió (ENTREVISTA , 2009 :2).

Ferviente devota del culto guadalupano, Romero se identifica con una deidad femenina :

(...) venero a una deidad femenina, no tengo al Cristo, me parece una fortuna haber nacido mexicana. Y tener a la Virgen de Guadalupe, desde 1984 hago algo para la Virgen. Hacer un performance, una conferencia, esta acción Cihuayo... (ENTREVISTA, $2009: 2)$

69 El ritual consistió en extraer algunas gotas de sangre punzando los labios menores de la vulva con dos puntas de maguey que portaban pequeñas cintas rojas, con el objetivo de depositar el líquido vital sobre papel de maguey. Ofrenda que fue quemada en el altar doméstico en honor de la Virgen de Guadalupe. De ahí que el ritual haya tenido lugar el 11 de diciembre de 2006 la víspera de la celebración de la fiesta de la Virgen.

El registro fotográfico lo realizó Federico Gama, por su trabajo ha sido reconocido en países como México, Estados Unidos, Canadá, Colombia, entre otros. La intervención corporal la ejecutó Katia Tirado, artista del performance quién también se dedica a la ingeniería del cuerpo y el tatoo. Ella perforó los labios en los que colocó las dos pequeñas argollas.

71 En la habitación de la artista, la cama matrimonial se encontraba custodiada por la imagen de la Virgen de Guadalupe. Era una enorme manta roja que pendía desde el techo. Sobre la cama cubierta con sábana de satén rojo yacía el cuerpo desnudo de Elizabeth Romero, en posición decúbito supino, con las piernas colocadas en triangulo pubiano, el brazo derecho hacia arriba y el izquierdo hacia abajo, la cara hacia un lado. Gama, captó la imagen fotográfica en primer plano, focalizando la intervención del área genital con las puntas de maguey perforando los labios. 
Elizabeth Romero, Cihuayo, detalle

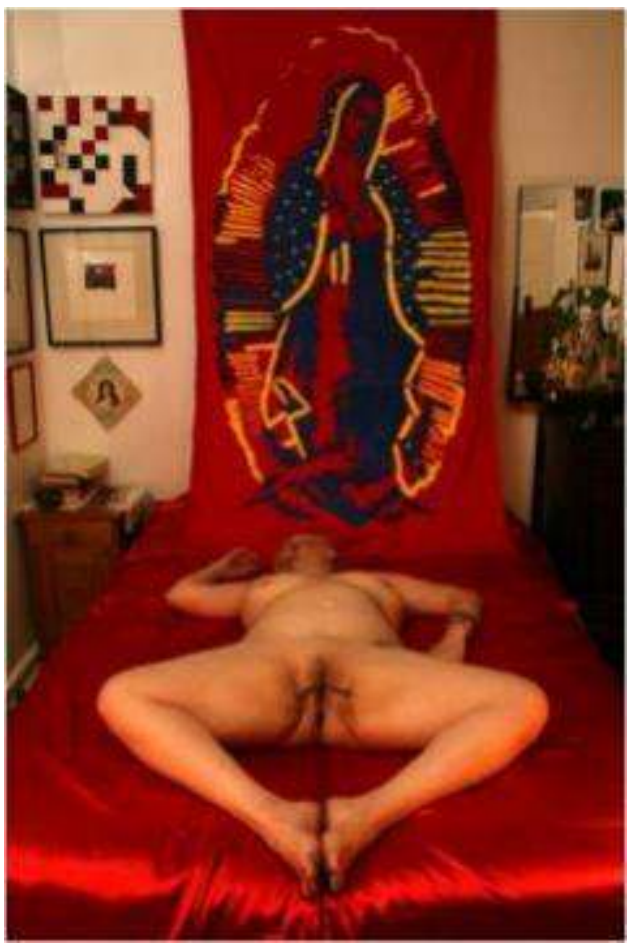

Performance, fotografía federico gama, MÉXICO, D.F., 2006.

Cortesía de Elizabeth Romero

Elizabeth Romero, Cihuayo, detalle

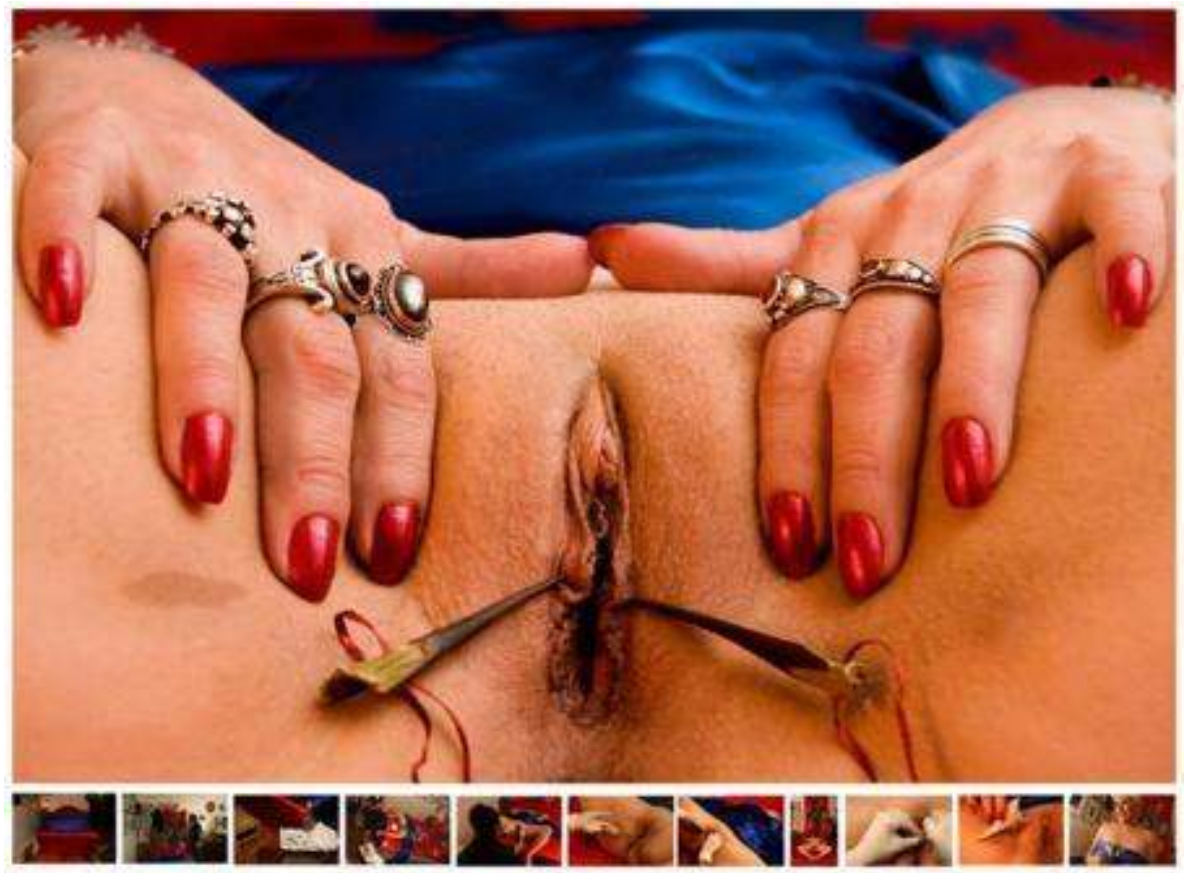

PERFORMANCE, fOTOgRAFía FEderico GAMA, MÉXICO, D.F., 2006.

Cortesía de Elizabeth Romero 


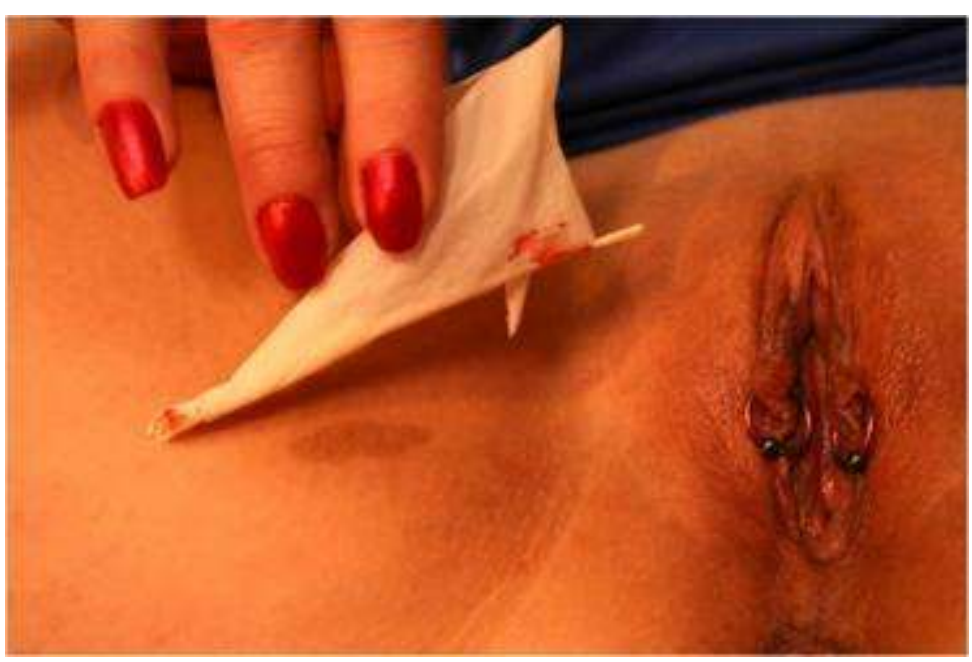

PERformance, fotografía federico GaMA, MÉXico, D.F., 2006.

El impacto visual que logran las imágenes resulta conspicuo por la carga polisémica que involucra elementos deconstructores de la simbolización de la feminidad, que de acuerdo con la interpretación de Romero, remite a la iconografía cristiana, toda vez, que se puede apreciar que por su forma, la vagina se asocia con la forma de la mandorla, un marco o aureola en forma oval o de almendra en donde se insertan personajes sagrados, especialmente las imágenes del culto Mariano y Guadalupano :

Me importaba reconocer en la forma de la vagina, la mandorla, que es una forma de almendra, de hecho mandorla en italiano significa almendra, aparece en gran parte de la iconografía mariana cristiana. Esta forma de mandorla es la que tienen muchas representaciones de vírgenes y es especialmente significativa en la iconografía guadalupana. Y esta almendra es la forma más sintética de la vulva. Esa es la forma que tiene una vulva, una mandorla. Entonces hay para mí esta comprobación de que al adorar a la virgen adoramos al arquetipo de la síntesis de la feminidad que es la vulva, no tanto la vagina, es la vulva lo que estamos adorando, y esto puede ser inconsciente en la actualidad, nadie aceptaría que cuando venera a la -Virgen de Guadalupe adora a la vulva, nadie es consciente-. Pero hay una representación inconsciente de esa forma en cada imagen. Es una parte que puede ser muy impactante para la gente. Si tú ves la imagen de la vulva, ves la imagen de la Virgen, el capuchón del clítoris sería la cabeza de la imagen y los labios, serían el manto, y lo que es la mandorla, todo el borde de la vulva de la entrada de la vagina. Yo pienso que inconscientemente, y no sé desde cuando, al adorar a esta forma en realidad estamos adorando a la forma de la feminidad. La más primaria, la más elemental, la más sintética de la feminidad (ENTREVISTA , 2009 :1).

En este sentido, Romero, utiliza sus genitales como soporte corporal para crear una metáfora visual de la simbolización de la feminidad, asociada a la iconografía guadalupana. La artista aduce que la imagen de la vulva femenina confronta a la gente, sobre todo, porque es una parte oculta, misteriosa, tabú, que ni las propias mujeres conocen. Ahora verla con las puntas de maguey resulta sumamente impactante. La consideran dolorosa, horrible, desconcertante, no la decodifican. Asimismo, señala que su idea no fue mostrar la vagina o darle una connotación sexual, por este motivo, la imagen 
mostró la vulva sin vello púbico, lo cual no le confirió una connotación sexual o erótica. De acuerdo con su testimonio :

Hubo una mujer que la vio y me confesó que se fue luego a mirar en un espejo. 0 sea despertó su curiosidad y su deseo de ver su propio sexo. Hay otra mujer que la vio y soñó con ella. Y hay un hombre que me dijo que era hermosamente dolorosa ( ENTREVISTA , $2009: 3)$.

Para ella este performance representó un motivo de orgullo :

Creo que hay demasiada censura afuera, aparatos de vigilancia y esos aparatos y fuerzas represoras siempre censuran todo. $Y$ creo que la peor censura que puede haber es la autocensura. Yo necesitaba hacer esto tener esta imagen de mis genitales y no me censuré. $\mathrm{Y}$ eso me da mucho gusto. No haber tenido ese impulso de lo que quiero hacer, o que van a pensar de mí. Al ver la imagen ya impresa mi sensación es de haber hecho algo importante, de haberle dado visibilidad a mis genitales. Eso me parece muy importante, no los vemos. $Y$ hay mujeres que nunca se han mirado. Y quizá, nunca se atrevan a mirarse. Hay un tabú sobre la visibilidad de la genitalia. Entonces poder verlos me parece importante y constatar también a final de cuentas la belleza y la simpleza de la genitalia (ENTREVISTA , 2009 :2).

Sin duda Cihuayo constituye un referente artístico de cómo opera la subjetividad femenina que ha conquistado su derecho a la autorepresetación. Elizabeth Romero está consciente de ello y de su empoderamiento como mujer, ya que para ella ser dueña de su cuerpo :

Tiene que ver con esta posibilidad de punzarlo, saber cosas de mí, mi sangre me habla de mí. Para mí, la sangre es vida, tengo relación con la sangre como mujer, tengo una cita mensual con la sangre. (...) Me importa mucho descifrar el cuerpo, el lugar donde yo lo hago es mi propio cuerpo y en el sentido de conocerlo y explorarlo, y conocer sus límites de saber de su anatomía, fisiología, historicidad, entre más se de mi cuerpo más me lo apropio. Y tanto mi goce como mi dolor me informan de mi cuerpo y de mí. Mi cuerpo soy yo. (...) Hay que conocer el cuerpo, enunciarlo, exhibirlo como una forma de apropiarse la persona de sí misma. Y esta soberanía es mi cuerpo. No es el cuerpo que la familia quiere, que el Estado quiere, es el que yo he construido, que he enunciado. (...) Mi idea es que yo tengo un cuerpo sublevado de lo que me han enseñado de lo que se esperaba de mí, de la expectativa social y religiosa, de lo que se esperaba de un cuerpo de mujer. Yo tengo un cuerpo sublevado y lo he hecho mío (ENTREVISTA , 2009 :4).

77 En conclusión, desde su emergencia en la década de los setenta y hasta la actualidad, el arte de la transgresión se ha constituido en una poderosa estrategia subversiva de las artistas comprometidas con el feminismo para cuestionar y desnaturalizar los discursos de la cultura visual hegemónica sustentados en la lógica binaria que polariza las relaciones de género en el patriarcado. La diversidad de sus narraciones visuales involucra una notable tarea deconstructiva, a partir de la construcción del discurso visual que vindica el derecho de las mujeres a la autorrepresentación. Y, por ende, expresa y visibiliza la alteridad de la subjetividad femenina en su diversidad creativa. Es un discurso que coadyuva a la creación de una mirada dialógica de empoderamiento de la representación de la identidad femenina en el arte.

En opinión de Lourdes Méndez (2004:137), antropóloga del arte, desde la década de los noventa y principios del siglo XXI los códigos visuales utilizados por algunos y algunas artistas resultan innovadores, ya que mediante ellos se cuestionan estereotipos y valores dominantes con los que se construye una posible y única realidad. Se trata de una labor de deconstrucción de imágenes y de referentes culturales que conciernen al cuerpo y cuya plasmación artística propone interpretaciones, símbolos, imágenes sobre las mujeres y los 
hombres, acerca del erotismo, la sexualidad, la « raza » y la identidad de los sujetos sexuados a menudo inquietantes y perturbadoras.

Un hecho es incontrovertible, el recurso de la transgresión en el arte, se ha revelado como un poderoso medio utilizado por las creadoras para subvertir la mirada de la representación dominante. Esta actitud irreverente, ha contribuido a la deconstrucción de la representación del género ideada por los valores de la cultura hegemónica, afirmando con ello, el derecho a la diferencia dialógica sin oposición de las identidades sexuadas.

\section{BIBLIOGRAFÍA}

ABELleyra Angélica, "Rowena Morales y Carlos Aguirre", Ciudad de México, La Jornada, 13 agosto, $\mathrm{s} / \mathrm{p}, 1985$.

ACHA Juan, Las culturas estéticas de América Latina, Ciudad de México, UNAM, 1993.

BARBoSA SÁNCHEZ Alma, La intervención artística de la ciudad de México. Ciudad de México, Conaculta, IMBA, Cenart, Instituto de Cultura de Morelos, 2003.

BARBOSA SÁNCHEZ Araceli, Arte feminista en los ochenta en México. Una perspectiva de género. Ciudad de México, Casa Juan Pablos Editores, Universidad Autónoma del Estado de Morelos, 2008.

BECKER Udo, Enciclopedia de los símbolos, Ciudad de México, Editorial Océano, 1998.

DEL CONDE Teresa, Historia mínima del arte mexicano en el siglo XX, Ciudad de México, Ediciones

ATTAME, 1994.

EDER Rita, “El arte público en México Los Grupos”, Artes Visuales, n²3, Ciudad de México, Invierno, 1980, p. III.

Entrevista a Elizabeth Romero, copia impresa, archivo personal Elizabeth Romero, 2009.

FRANCO Jean, “Invadir el espacio público; transformar el espacio privado”, Ciudad de México, Debate Feminista, año 4, vol. 8, septiembre, 1993, pp. 267-287.

GARCíA CANCLINI Néstor, La sociedad sin relato. Antropología y estética de la inminencia, Ciudad de México, Katz editores, 2011.

LAGARDE Marcela, Los cautiverios de las mujeres: madresposas, monjas, putas, presas y locas, Ciudad de México, Facultad de Filosofía y Letras. Colección Posgrado, Universidad Nacional Autónoma de México, 1993.

Lau Jaiven Ana, La nueva ola del feminismo en México, Ciudad de México, Planeta, 1987.

LÓPEZ AUSTIN Alfredo, Cuerpo humano e ideología. Las concepciones de los antiguos nahuas, Ciudad de México, Universidad Nacional Autónoma de México, Instituto de Investigaciones Antropológicas, t. I, Serie Antropológica : 39, 1996.

LUGO MARTÍNEZ Pablo Angel, El arte transgresor, un acercamiento a la rebeldía, un valor en el arte del siglo XX, Valencia, Universidad Politécnica de Valencia, Facultad de Bellas Artes de San Carlos, Departamento de Escultura, Versión PDF, 2010. 
MARCHÁ FIZ Simón, Del arte objetual al arte del concepto, Madrid, Akal, 1990.

MARTÍNEZ RENTERÍA Carlos, "El que escribió en París la frase 'La imaginación al poder' fui yo", Ciudad de México, suplemento Sábado del unomásuno, 31 de octubre, 1998, p.2.

MAYER Mónica, Traducciones: Un diálogo internacional de mujeres artistas, Ciudad de México, fotocopia, archivo personal Mónica Mayer, 1979-1980.

MAYER Mónica, “De mujeres artistas y conferencias”, Ciudad de México, El Universal 19

septiembre, s/p, 1995.

MÉNDEZ Lourdes, Cuerpos sexuados y ficciones identitarias. Ideologías sexuales, deconstrucciones feministas y artes visuales, Sevilla, Colección Hypatia, Instituto Andaluz de la Mujer, 2004.

MORIN Edgar, Introducción al pensamiento complejo, 8ª.reimpresión, edición española a cargo de Marcelo Pakman, Barcelona, Gedisa, 2005.

MORIN Edgar, El método 3. El conocimiento del conocimiento, 6à. ed., Ana Sánchez (trad.), Madrid, Cátedra (Colección Teorema), 2009.

MURo María, "No renuncié al MAM, me corrieron, dice Manrique”, Ciudad de México, unomásuno, 26 febrero, 1998, p. 23.

NEAD Lynda, El desnudo femenino. arte, obscenidad y sexualidad, Madrid, Editorial Tecnos, S.A., Colección Metrópolis, 1998.

SESín Saide, "La fuerza del erotismo y la energía de la mujer en el grabado de Ninik Sauret", Ciudad de México, unomásuno, 21 marzo, 1986, s/p.

TUÑón Esperanza, Mujeres en la Escena : De la tramoya al protagonismo. (1982-1994), Ciudad de México, Programa Universitario de Estudios de Género, UNAM, 1997.

VARGAS Ángel, “Arte de Chiarito, insoportable para las buenas conciencias”, Ciudad de México, La Jornada, Cultura, La Jornada de en medio, 16 de julio, 2000 a, p. 5.

VARGAS Ángel, “La exposición Homenaje al lápiz, sometida a la censura en Jalisco”, Ciudad de México, La Jornada, Cultura, La Jornada de en medio, 6 agosto, 2000 b, p. 2.

VÁZQUeZ MANTECón Álvaro, Los Grupos : Entrevista a Magali Lara. Programa video-catálogos, Ciudad de México, D.F., Museo de Arte Alvar y Carmén T. de Carrillo Gil, 1994

Entrevistas

JIMÉNEZ Ana Victoria, Ciudad de México, D.F., casa de la artista, 1999.

LARA Magali, Ciudad de México, D.F., Museo de Arte Alvar y Carmén T. de Carrillo Gil, 1998.

MAYER Mónica, Ciudad de México, D.F., casa de la artista, 1997, 1999.

ROMERo Elizabeth, Ciudad de México, D.F., Casa de la artista, 2009.

\section{NOTAS}

1. El concepto de la transgresión adquiere connotaciones positivas o negativas dependiendo de su contexto cultural e histórico, por lo tanto, implica un posicionamiento desde el relativismo moral. Así por ejemplo, entre los griegos la transgresión de la norma se justificaba en la medida que cumpliera con condiciones que redundaran en aspectos fundamentales para el bien común de la sociedad. El resultado de la transgresión debería derivar en el bienestar colectivo. 
Asimismo, el transgresor tenía que ser sancionado de forma individual, ya que se consideraba que se había sacrificado por una causa común, constituía un ejemplo, representaba al héroe, -el ejemplo más representativo es Prometeo, el titán responsable de separar los bienes y la riqueza entre los olímpicos y los hombres-, por el contrario, un castigo que se infligiera más allá del/los transgresores, se consideraría como una injusticia. (LUGO, 2010 :53-54).

2. Conforme a la epistemología de la complejidad, el principio dialógico se concibe como la unión de dos términos o nociones antagónicas que aparentemente debieran rechazarse entre sí, no obstante, ser indisociables para comprender una misma realidad. Es un principio de unidad que asume el carácter dialógico de toda relación ya que permite mantener la dualidad en el seno de la unidad (MORIN, 2005).

3. La propuesta teórica de la complejidad es dilucidada por Edgar Morin en los siguientes términos : "A primera vista la complejidad es un tejido (complexus : lo que está tejido en conjunto) de constituyentes heterogéneos inseparablemente asociados : presenta la paradoja de lo uno y lo múltiple. Al mirar con más atención, la complejidad es, efectivamente, el tejido de eventos, acciones, interacciones, retroacciones, determinaciones, azares, que constituyen nuestro mundo fenoménico. Así es que la complejidad se presenta con los rasgos inquietantes de lo enredado, de lo inextricable, del desorden, la ambigüedad, la incertidumbre... De allí la necesidad, para el conocimiento, de poner orden en los fenómenos rechazando el desorden, de descartar lo incierto, es decir, de seleccionar los elementos de orden y de certidumbre, de quitar ambigüedad, clarificar, distinguir, jerarquizar... Pero tales operaciones, necesarias para la inteligibilidad, corren el riesgo de producir ceguera si eliminan a los otros caracteres de lo complejo" (MORIN, 2005 :3).

4. Joseph Kosuth, crítico primero, y después uno de los principales representantes de esta corriente, realizó en 1968 una obra titulada Una y tres sillas ; consistía en una silla común, una fotografía de ella, y una fotocopia ampliada de la definición de la palabra silla en el diccionario. En síntesis, el objeto, la representación y la definición. Los tres informan acerca de esa realidad; se plantean problemas lógicos, semánticos, que transforman la esencia de lo, hasta el momento considerado artístico. Ya no serán las características, dimensiones o formas de un objeto determinado las que contarán en el futuro, sino el proceso que permitió llegar a ellas. Sol Lewitt define al "arte conceptual" o "arte de las ideas" en los siguientes términos: "En el arte conceptual la idea o concepto es el aspecto más importante de la obra. Cuando el artista se vale de una forma de arte conceptual, significa que todo el proyecto y las decisiones se establecen primero y la ejecución es un hecho mecánico. (apud Marchán, 1990 :249-271).

5. En el campo de la representación femenina, resultan sumamente interesantes y revolucionarias las obras de las artistas Frida Kahlo, Nahui Olin o Remedios Varo, por abordar desde la autorepresentación de su subjetividad erótica y sexual, su identidad femenina. Frida Kahlo se atrevió a pintar los aspectos más íntimos de su vida, como sus abortos, su idolatría por Diego, sus obsesiones maternas, su sexualidad, la exuberante naturaleza pletórica de órganos genitales, sus autorretratos, en los que una y otra vez subvierte su propia imagen, etcétera. Nahui Olin, por su parte, hace gala de su desbordante erotismo y voluptuosidad al autorretratarse desnuda y en plena cópula amorosa con sus amantes. Remedios Varo recreó en sus obras, de manera implícita, mucho del pensamiento referido a la energía sexual ligada al universo. (BARBOSA, $2008: .49$ ).

6. El surgimiento de lo que ahora se conoce como el feminismo de nuevo tipo emergió en México en el inicio de la década de los setenta como respuesta a los cambios socioculturales gestados en el ámbito nacional e internacional. Ver Lau Jaiven (1987).

7. Suástica, cruz gamada, una cruz de cuatro ramas iguales y provistas de una prolongación en ángulo recto o en arco que sugiere un movimiento rotatorio; también puede considerarse formada por cuatro perpendiculares, a veces invertidas, de ahí el nombre de cruz gamada. Es un protosímbolo muy arcaico del que se tiene noticia en la cultura occidental desde el siglo V. a.c., 
como aparece en la tablilla de Samarra, y en la cultura oriental desde un periodo similar en las esculturas búdicas sino-tibetanas. Cruz gamada. Su papel como símbolo político del régimen nocionalsocialista debe atribuirse a la sobrevaloración romántica de la « germanidad » de finales del siglo pasado y comienzos del actual. De 1935 a 1945, la cruz gamada debajo del águila imperial (negra sobre fondo blanco) fue símbolo del «Tercer Reich». (BECKER 1998 :131). En su obra, Mayer utiliza la cruz gamada búdica, símbolo de transformación y perfeccionamiento espiritual, en vez de aludir a la suástica nazi, como era su intención.

8. Comunicación personal Mónica Mayer, 13 de enero de 1999. Años más tarde, en 1988, se presentará la exposición del pintor Rolando de la Rosa, en el Museo de Arte Moderno, de la ciudad de México, en la que exhibirá los fotomontajes con los rostros sobrepuestos de Marilyn Monroe y Pedro Infante a las imágenes de la Virgen de Guadalupe y Cristo, respectivamente, que costará el puesto al entonces director del museo Jorge Alberto Manrique, como represalia de los grupos católicos, quienes consideraron la exposición como un insulto a la religión y una violación al derecho de creencia, por lo que exigieron desmontar la muestra. Estas fueron las palabras de Jorge Alberto Manrique respecto de su renuncia. "Me parece lastimoso que el Estado ceda a las peticiones de los grupos más retrógrados de la sociedad mexicana". "No renuncié al MAM, me corrieron, dice Manrique", (MURO, 1988 :p.23). Otro acontecimiento que demuestra la intolerancia hacia las alusiones al erotismo y los iconos sagrados ocurrió el mes de agosto del 2000. Dentro de la comunidad artística e intelectual causó gran conmoción la decisión que tomó la directora del Museo del Periodismo y las Artes Gráficas, de Guadalajara, Jalisco, Yolanda Carvajal Enríquez, de censurar 13 de las 200 obras que integraban la exposición Homenaje al lápiz. La funcionaria envió un par de escritos al Museo José Luis Cuevas, organizador de la muestra, en donde asevera que las obras "no se exhiben por su contenido erótico, puesto que 60 por ciento de los visitantes son adolescentes", y agrega, éstos "no tienen criterio para asimilarlo con madurez. Por otra parte, la sociedad tapatía es aún demasiado conservadora". Lo cierto es que entre las obras censuradas se encontraba la obra de Manuel Ahumada La patrona, en la cual aparece Juan Diego portando en su ayate la imagen desnuda de Marilyn Monroe. Tiempo después se efectuó la exposición con las obras censuradas, sin embargo, la obra de Ahumada fue agredida con ácido por un par de jóvenes. (VARGAS, 2000 (b) :.2). Finalmente, hay que citar otra exposición que sufrió los embates de la intolerancia. Inaugurada el 11 de julio de 2000, la exposición El mundo de Robert Chiarito, en el Centro Cultural de Tlalpan, resultó "demasiado escandalosa para los padres de familia", por lo que la directora Magda Hofmann decidió voltear las obras contra la pared. De acuerdo con su propio testimonio, Hofmann tomó tal medida presionada por los padres de familia, quienes calificaron la exposición de inmoral, pornográfica y hasta satánica. (VARGAS, 2000 (a) :5).

9. Para más información acerca del Arte Feminista en México, consultar (BARBOSA, 2008).

\section{RESÚMENES}

En México en la década del 1970/80, el discurso de la transgresión en el arte femenino irrumpe con la emergencia de las obras de aquellas creadoras que plantean temáticas políticamente "incorrectas" que desafían al mainstream de la representación visual hegemónica. Desde la “epistemológica de la complejidad", que postula la perspectiva "dialógica" de la realidad fenoménica, sus propuestas estéticas devienen conspicuas, toda vez que deconstruyen la dicotomía masculino/femenino que polariza las relaciones de género en el patriarcado. Por ende, 
sus narrativas visuales promueven una mirada dialógica de la representación de la alteridad femenina en el arte. Asimismo, el concepto de la transgresión asume la idea de ruptura con el dualismo clásico para gestar el cambio hacia nuevos paradigmas artísticos.

Conformément à l'épistémologie de la complexité, l'analyse phénoménologique implique l'existence des logiques que par sa condition dialogique assument le caractère d'indétermination et d'ambigüité de tout phénomène. Cette analyse permet de surmonter la logique dichotomique occidentale, qui simplifie la complexité à travers la vision réductrice des opposés. De cette manière, par exemple, le binôme transgression/libération est essentiel afin de concevoir le changement vers des nouveaux paradigmes. Dans le contexte mexicain des années 1970 et 1980, l'art de la transgression dans la plastique féminine se manifeste avec des thématiques politiquement incorrectes.

\section{ÍNDICE}

Palabras claves: complejidad, transgresión y dialógica, arte mujeres, arte mexicano, arte latinoamericano, México

Mots-clés: complexité, transgression et dialogique, art femmes, art mexicain, art latinoaméricain, Mexique, Mexico

\section{AUTOR}

\section{ARACELI BARBOSA SÁNCHEZ}

Doctora en Historia del Arte por la Universidad Nacional Autónoma de México, profesora investigadora de la Universidad Autónoma del Estado de Morelos. Autora de los libros "Educación y Arte para la Sustentabilidad", Juan Pablos, UAEM, 2015, así como "Arte Feminista en los ochenta en México. Una perspectiva de género", Juan Pablos, UAEM, 2009. Líneas de investigación arte, "género", ambiente.

araceli_barbosa[at]uaem.mx 